noted late in the afternoon always exceeded that of the morning. These parameters can be used to measure the length of the period of adaptation to a new environment when mixing animals together or when conveying animals to other places.

\title{
LE SEVRAgE DES PORGELETS A 5 SEMAINES ET A 8 SEMAINES RÉSULTATS TECHNIQUES ET ÉCONOMIQUES D'UN ESSAI CONDUIT DANS LES ÉLEVAGES
}

\author{
Établissements départementaux d'Élevage \\ Station de Recherches sur l'Élevage des Porcs, \\ Centre national de Recherches zootechniques, I. N.R. A., \\ 78350 Jouy en Josas \\ I.T.P., M. N.E. - Sevvice Expérimentation, \\ 147-149, rue de Bercy, \\ Paris $7^{\mathrm{e}}$
}

\section{RÉSUMÉ}

La comparaison de deux dates de sevrage, 5 semaines et 8 semaines, a été effectuée dans les conditions de la pratique, sur des couples de truies appariées d'après leur nombre de mise bas et la taille de leurs portées.

Sur r 20 couples de portées, on observe les résultats suivants, respectivement pour les sevrages à 5 semaines et à 8 semaines :

- nombre de portées ayant subi des pertes entre 5 et 8 semaines : $24 ; 3$ ( $\mathrm{p}<\mathrm{o}, \mathrm{oor}$ );

— nombre de porcelets à 5 semaines : 9,$43 ; 9,46(\mathrm{NS}) ;$ à 8 semaines $: 9,13 ; 9,43$ (NS) ; à 9 semaines : 9,$13 ; 9,4 \mathrm{I}$ (NS)

— Poids moyen des porcelets à 8 semaines $(\mathrm{kg}) ; 15,45 ; 16,62(\mathrm{p}<0,0 \mathrm{I})$ et à 9 semaines : 19,20 ; I9,9r $(\mathrm{P}<\mathrm{o}, \mathrm{OI})$;

- Consommation d'aliment par porcelet $(\mathbf{k g})$;

entre 5 et 8 semaines : I3,39; Ir,53 ( $\mathrm{P}<0,00 \mathrm{I})$;

entre 8 et 9 semaines : $7,6 \mathrm{I} ; 7, \mathrm{II}(\mathrm{P}<\mathrm{o}, \mathrm{or})$.

Sur I I 2 couples de truies, on observe les résultats suivants ; respectivement pour les sevrages à 5 et 8 semaines :

- Consommation d'aliment en lactation (kg); I79; 289 (P < o,oor);

- Intervalle sevrage-rer chaleur $(j): 9,4 ; 7,9$ (NS).

- Intervalle, sevrage-saillie fécondante $(j):$ I 3,I ; I2,9 (NS).

Les dépenses en aliment lactation et porcelets sont de 30,21 $\mathrm{F}$ et de 33,66 $\mathrm{F}$ par porcalet de 63 jours sevré respectivement à 5 ou 8 semaines $(\mathrm{P}<0.00 \mathrm{I})$.

On conclut que, dans les conditions de la pratique, le sevrage à 5 semaines permet un gain de 0,26 portée par an et de $2 \mathrm{~F}$ d'alimentation par porcelet de $20 \mathrm{~kg}$ par rapport au sevrage à 8 semaines. 


\title{
SUMMARY \\ WEANING OF PIGLETS AT 5 AND 8 WEEKS : \\ TECHNICAI, AND ECONOMIC RESUI,TS OF A TRIAI, PERFORMED \\ IN SEVERAL FARMS
}

Comparison of two dates of weaning, 5 and 8 weeks, was made in the practice between couples of sows grouped according to number of farrowings and size of litters.

The following results were observed with $\mathrm{t} 20$ couples of litters weaned at 5 or 8 weeks respectively :

- number of litters with losses between 5 and 8 weeks : $24,3(\mathrm{P}<0,00 \mathrm{O})$;

- number of piglets at 5 wceks : $9.43,9.46$ (NS) ;

at 8 weeks : $9.13,9.43$ (NS) ;

at 9 weeks : $9.13,9.4 \mathrm{I}$ (NS).

- mean weight of piglets at 8 weeks $(\mathrm{kg}): 15.45, \mathrm{I} 6.62(\mathrm{P}<0.0 \mathrm{I})$ and at $9: 19.20$, I9.9 I $(\mathrm{P}<0.01)$.

— feed intake per piglet $(\mathrm{kg})$ between 5 and 8 weeks : 13.39, I I.53 $(\mathrm{P}<0.001)$;

between 8 and 9 weeks : 7.6I, 7.II $(\mathrm{P}<0.0 \mathrm{I})$.

The following results were observed with II 2 couples of sows, weaned at 5 and 8 weeks repectively :

-- feed intake during lactation $(\mathrm{kg}): 179,289(\mathrm{P}<0.00 \mathrm{I})$; interval between weaning and first œstrus (D) : 9.4, 7.9 (NS) ; interval between weaning and conception (D) : I 3.I, I 2.9 (NS).

The cost price of lactation feed for the sows and starter feed for the piglets were $30.2 \mathrm{I} \mathrm{F}$ and $33.66 \mathrm{~F}$ per 63 days old piglets weaned at 5 or 8 weeks respectively.

It may be concluded that in practice weaning at 5 weeks, compared with that at 8 weeks, results in a gain of 0.26 litter per year and a sparing of feed ( 2 francs per piglet of $20 \mathrm{~kg}$ ).

\section{AgE AU SEVIAGE CHEZ LE PORCELET : hEPERCUSSION SUR LA PHODUCTIVITÉ DES TRUIES ET INFLUENCE SUR LES JEUNES ANIMAUX}

\author{
A. AUMAITRE et J. RETTAGLIATI \\ Station de Recherches sur l'Elevage des Porcs, \\ Centre national de Recherches zootechniques, I. N. R. A., \\ 78350 Jouy en Josas
}

\section{RÉSUMÉ}

Le sevrage précoce des porcelets constitue l'un des moyens d'augmenter la productivité de la Truie en réduisant la durée d'allaitement, période considérée classiquement comme infertile chez cet animal. 